\title{
Van evidence- naar practice-based medicine
}

EVIDENCE-BASED PRACTICE (EBP) is het mantra in de moderne geneeskunde: pas alleen diagnostiek en behandelingen toe op basis van wetenschappelijk bewijs. Deze worden vertaald naar medische richtlijnen, protocollen en standaarden. Tussen de eerste inzichten uit onderzoek en de uiteindelijke toepassing van zo'n richtlijn zit tien tot vijftien jaar. De houdbaarheid in de praktijk is iets meer dan vijf jaar. Dan is die achterhaald door nieuwe inzichten. Uitdaging is dat de richtlijn gebaseerd is op de 'gemiddelde patiënt' terwijl de praktijk een stuk complexer kan zijn.

Daarom mogen artsen afwijken van de richtlijn zolang ze dat motiveren in het dossier. Dit gebeurt echter weinig. De Raad voor Volksgezondheid en Samenleving publiceerde in 2017 het rapport Zonder context geen bewijs - Over de illusie van evidence-based practice in de zorg.

Over naar die praktijk: een van de meest voorkomende klachten bij de huisarts is de urinewegontsteking bij vrouwen. Op basis van de (EBP-)standaard wordt meestal antibiotica voorgeschreven die in circa 20 procent van de gevallen niet werkt. Een jonge big-data-onderneming uit Amsterdam heeft de achterliggende factoren onderzocht aan de hand van een database van ruim 200.000 urineweginfecties. Hierdoor beschikken ze over een uitgebreide onderzoekspopulatie met grote diversiteit qua persoonskenmerken en comorbiditeit. Dit systeem kan dus gerichter analyseren wat wanneer en bij wie werkt. Met behulp van machine learning is een zelflerend model gebouwd dat de verwachte uitkomst van de mogelijke behandelingen presenteert inclusief die uit de standaard. De overwegingen bij de behandelkeuze zijn daarmee veel specifieker geworden en de uiteindelijke behandelkeuze die de huisarts maakt samen met de patiënt relevanter. 116 huisartsen doen mee in een implementatiestudie van deze 'personalized medicine' en de vooruitzichten zijn veelbelovend. Verwacht wordt dat het percentage ineffectieve behandelingen bij vrouwen met 15 procent en bij mannen met 38 procent kan dalen. Dat scheelt 50.000 herhaalconsulten en antibioticakuren in Nederland.

Ook PROMs, patient reported outcome measures, verkregen door patiënten voor en na een behandeling een gestructureerde vragenlijst voor te leggen, dragen bij aan personalized medicine. Ze geven inzicht niet alleen in de medische uitkomsten, maar ook het effect van de behandeling in de beleving en context

van de patiënt zelf. De groeiende PROMsdatabases geven allerlei nieuwe inzichten in relaties tussen kenmerken van patiënten, mogelijke behandelingen en uitkomsten. Sterker nog, door verdere analyses op de databases is het mogelijk de kansen op succesvolle uitkomsten van chirurgie, bijvoorbeeld bij voet- en enkeloperaties, te voorspellen. Vergelijking van individuele patiëntscores met PROMs op populatieniveau draagt bij aan een betere keuze voor wel of niet opereren. Deze ontwikkeling geeft de patiënt een actieve stem in de dialoog met de arts over behandeldoel en -beleid.

Zo kunnen machine learning en bigdata-analyse op basis van persoonspecifieke epd-data en een omvangrijke populatiegerichte database een behandeling opleveren die gericht is op de individuele patiënt. Op naar practice-based medicine met AI en big data!
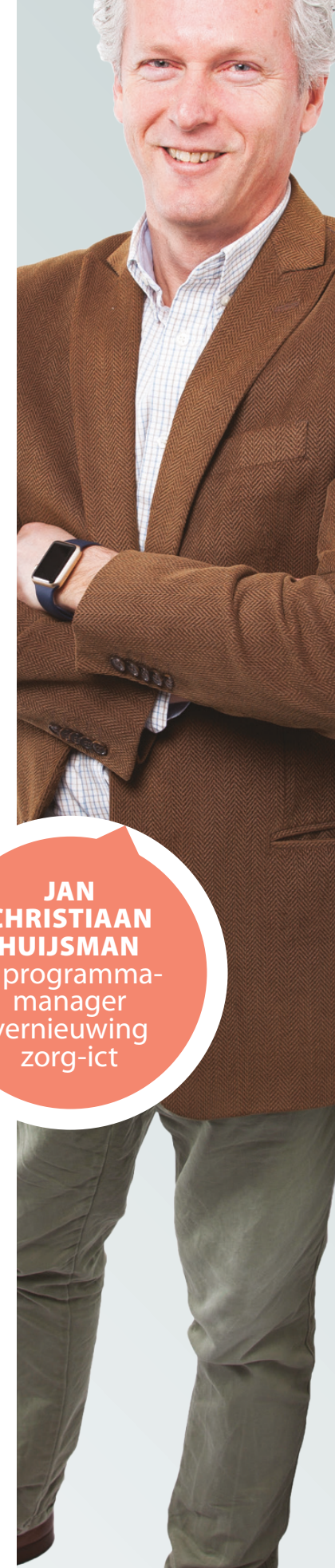